\title{
EVALUASI PENERAPAN SISTEM INFORMASI MANAJEMEN DAERAH (SIMDA) PADA DINASS PENDAPATAN, PENGELOLAAN KEUANGAN DAN ASSET DAERAH KOTA KOTAMOBAGU
}

\section{EVALUATION OF IMPLEMENTATION OF REGIONAL MANAGEMENT INFORMATION SYSTEM (SIMDA) AT THE DEPARTMENT OF REVENUE, FINANCE AND ASSET MANAGEMENT OF URBAN KOTAMOBAGU}

\author{
Oleh: \\ Veybie Komaling ${ }^{1}$ \\ Stanley Kho Walandow ${ }^{2}$ \\ ${ }^{1,2}$ Fakultas Ekonomi Dan Bisnis, Jurusan Akuntansi \\ Universitas Samratulangi Manado \\ e-mail: ${ }^{1}$ vkomaling@yahoo.com \\ 22stanleykho99@yahoo.com
}

\begin{abstract}
Abstrak:Program aplikasicomputer SIMDA adalah suatu program aplikasi yang ditunjukan untuk membantu Pemerintah Daerah dalam pengelolaan keuangan daerahnya. Adapun yang menjadi tujuan atas penlitian yang dilakukan adalah untuk mengevaluasi penerapan SIMDA pada Dinas Pendapatan, Pengelolaan Keuangan Dan Asset Daerah Kota Kotamobagu. Metode penelitian yang digunakan adalah data kualitatif, yaitu data yang diperoleh dari objek penelitian yang berbentuk kaimat atau uraian, sketsa maupun gambar dan data kuantitatif, yaitu data yang diperoleh objek penelitaian yang menyimpulkan bahwa Evaluasi Penerapan Sistem Informasi Manajemen Daerah (SIMDA) pada Dinas Pendapatan, Pengelolaan Keuangan Dan Asset Daerah Kota Kotamobagu belum sesuai dengan Peraturan Perundang-undangan yang berlaku, karena prosedur pengeluaran kas belum sesuai dengan Peraturan Menteri Dalam Negeri Nomor 13 tahun 2006 tentang Pedoman Pengelolaan Keuangan Derah.
\end{abstract}

Kata kunci: simda, penerapan simda

\begin{abstract}
Computer Applications SIMDA program is an application program that is intended to assist local governments in the area of financial management. As for the above purpose of the research is to evaluate the application of SIMDA at the Department of Revenue, Finance and Asset Management Regional Kotamobagu. Research methods using qualitative data, that is data obtained from the object of research in the form of sentences or descriptions, sketches and drawings and quantitative data, ie data obtained from the object of research in the form of numbers or numbers that have been processed further. From this study, the researchers concluded that SIMDA Application Evaluation in the Department of Revenue, Finance and Asset Management Regional Kotamobagu not fully in accordance with the Legislation in force, because the procedure is not in accordance with the cash outlay Minister Regulation No. 13 Year 2006 on Guidelines for Financial Management area.
\end{abstract}

Keywords: simda, evaluationsimda 


\section{PENDAHULUAN}

\section{Latar Belakang}

Untuk mendukung terwujudnya Good Governance dan Clean Government dalam penyelenggaraan otonomi daerah, perlu diselenggarakan pengelolaan keuangan daerah secara profesional, terbuka dan bertanggung jawab sesuai dengan aturan pokok yang telah ditetapkan dalam Undang-Undang. Good Governance merupakan isu relevan dalam pengelolaan administrasi publik.Pola-pola lama pemerintahan tidak sesuai lagi bagi tatanan masyarakat yang telah berubah.Oleh karena itu, Pemerintah perlu melakukan perubahan-perubahan yang terarah pada terwujudnya penyelenggaraan pemerintahan yang lebih baik.

Dalam Pengelolaan Data Keuangan Organisasi Pemerintah Daerah, perkembangan teknologi yang berkembang pesat merupakan salah satu faktor utama yang melatar belakangi dikembangkannya suatu sistem informasi berbasis komputer. Untuk memudahkan pengelolaan keuangan pada organisasi Pemerintah Daerah maka dikembangkan aplikasi Sistem Informasi Manajemen Keuangan Daerah atau SIMDA Keuangan.

Program Aplikasi Komputer SIMDA adalah suatu program aplikasi yang ditunjukan untuk membantu Pemerintah Daerah dalam pengelolaan keuangan daerahnya. Dengan aplikasi ini, Pemerintah Daerah dapat melaksanakan pengelolaan keuangan daerahnya secara terintegrasi, dimulai dari penganggaran, penatausahaan hingga akuntansi dan pelaporannya.

Untuk itu, Pemerintah Daerah memerlukan sistem yang dapat menghasilkan laporan keuangan dan informasi keuangan lainnya secara lebih komprehensif yang meliputi informasi mengenai posisi keuangan daerah, kondisi kinerja keuangan, dan akuntabilitas Pemerintah Daerah. Sistem tersebut juga harus mengacu pada Peraturan Pemerintah Nomor 58 Tahun 2005 tentang Pengelolaan Keuangan Daerah dan Peraturan Menteri Dalam Negeri Nomor 13 Tahun 2006 tentang Pedoman Pengelolaan Keuangan Daerah sebagaimana telah diubah beberapa kali terakhir dengan Peraturan Menteri Dalam Negeri Nomor 21 Tahun 2011 tentang Perubahan Kedua Atas Peraturan Menteri Dalam Negeri Nomor 13 Tahun 2006 tentang Pedoman Pengelolaan Keuangan Daerah.

Aplikasi SIMDA telah diterapkan oleh Pemerintah Kota Kotamobagu sebagai sistem informasi pengelolaan dan pelaporan keuangan dan barang milik daerah. Dan sejak diterapkan dapat dilihat adanya kemajuan dalam Laporan Keuangan Pemerintah Daerah Kota Kotamobagu.Namun demikian, masih terdapat kendala dalam pengelolaan SIMDA Keuangan. Minimnya SDM yang bisa mengoperasikan komputer menjadi salah satu penyebab terjadinya perangkapan tugas dan ketidaksesuaian pelaksanaan prosedur dalam proses pengelolaan keuangan daerah melalui aplikasi SIMDA Keuangan.

\section{Tujuan Penelitian}

Adapun yang menjadi tujuan atas penelitian yang dilakukan adalah untuk mengevaluasi penerapan SIMDA pada Dinas Pendapatan, Pengelolaan Keuangan Dan Aset Daerah Kota Kotamobagu.

\section{Tinjauan Pustaka}

Kieso dan Weygand menyatakan definisi akuntansi adalah suatu sistem informasi yang mengidentifikasi, mencatat, dan mengkomunikakan kejadian dari suatu ekonomidari suatu organisasi kepada pihak yang berkepentingan.

Dalam ABP (Acoounting Principle Board) statement No.4 akuntansi merupakan suatu kegiatan jasa yang berfungsi memberikan informasi kuantitatif, umumnya dalam ukuran meteri (uang), mengenai suatu badan ekonomi yang dimaksudkam untuk digunakan dalam pengambilan keputusan ekonomi, dimana digunakan dalam memilih beberapa alternarif.

Menurut AICPA (American Institute Of Certified Public Accountant) Akuntansi adalah seni pencatatan, penggolongan dan pengikhtisaran dengan cara tertentu dan dalam ukuran moneter, transaksi, dan kejadiankejadian yang umumnya bersifat keuangan dan termasuk menafsirkan hasil-hasilnya.

Akuntansi diartikan sebagai proses mengidentifikasikan, mengukur dan menyampaikan informasi ekonomi sebagai bahan informasi dalam hal mempertimbangkan berbagai alternative dalam mengambil kesimpulan oleh para pemakainya (ASOBAT).

Menurut American Accounting Assosiation, "Accounting as the process identifying, measuring and communicating economic information". Akuntansi merupakan proses mengidentifikasikan, mengukur dan 
melaporkan informasi ekonomi, untuk memungkinkan adanya penilaian dan keputusan yang jelas dan tegas bagi mereka yang menggunakan informasi tersebut. (Wilopo, 2005:9)

Akuntansi menurut Charles T. Horngren dan Walter T.Harisson adalah sistem informasi yang mengukur aktivitas bisnis, memroses data menjadi laporan, dan mengkomunikasikan hasilnya kepada para pengambil keputusan (Horngren Harisson, 2007:4).

\section{Pelaporan Keuangan}

Akuntansi lahir dengan maksud tertentu, yaitu untuk memberikan jasa kepada penggunanya berupa informasi keuangan yang dibutuhkan untuk proses pengambilan keputusan. Pada umumnya, laporan keuangan itu terdiri dari neraca, laporan laba-rugi, serta laporan perubahan modal, tetapi dalam praktik keseharian sering pula diikut sertakan kelompok lain yang sifatnya membantu memperoleh penjelasan, seperti laporan sumber dan penggunaan kas atau arus kas, laporan biaya produksi, dan lain-lain. Oleh karena itu, laporan keuangan dapat dipakai sebagai alat berkomunikasi dengan pihak-pihak berkepentingan dengan data keuangan perusahaan, 40ank arena itulah sering juga disebut sebagai language of business.

Menurut Surono Subekti (2006:9) menyatakan bahwa "Laporan keuangan merupakan salah satu informasi keuangan perusahaan yang terpenting."

Menurut Munawir (2010:31) mengatakan bahwa "Laporan keuangan merupakan alat yang sangat penting untuk memperoleh informasi sehubungan dengan posisi keuangan dalam hasil-hasil yang telah dicapai oleh perusahaan yang bersangkutan."

Jenis laporan keuangan bermacam-macam baik berupa laporan utama maupun laporan pendukung.Jenis-jenis laporan keuangan disesuaikan dengan kegiatan usaha perusahaan yang bersangkutan dan pihak yang keterkaitan untuk memerlukan informasi keuangan pada suatu perusahaan tertentu.

Menurut Ikatan Akuntan Indonesia (2007:1.2) menyatakan "Laporan keuangan yang lengkap terdiri dari lima, yakni laporan laba/rugi, laporan ekuitas pemilik, neraca, laporan arus kas, dan catatan atas laporan keuangan.

\section{Tujuan Laporan Keuangan}

Tujuan Laporan Keuangan menurut PAI adalah sebagai berikut :

a. Untuk memberikan informasi keuangan yang dapat dipercaya mengenai aktiva dan kewajiban serta modal suatu perusahaan.

b. Untuk memberikan informasi yang dapat dipercaya mengenai perubahan dalam aktiva netto (aktiva dikurangi kewajiban) suatu perusahaan yang timbul dari kegiatan usaha dalam rangka memperoleh laba.

c. Untuk memberikan informasi keuangan yang membantu para pemakai laporan di dalam menaksir potensi perusahaan dalam menghasilkan laba.

d. Untuk memberikan informasi penting lainnya mengenai perubahan dalam aktiva dan kewajiban suatu perusahaan, seperti informasi mengnai aktibitas pembiayaan dan investasi.

e. Untuk mengungkapkan sejauh mungkin informasi lain yang berhubungan dengan laporan keuangan yang relevan untuk kebutuhan pemakai laporan, seperti informasi mengenai kebijakan akuntansi yang dianut perusahaan.

\section{Sistem Akuntansi Pemerintahan Daerah Menurut Peraturan Menteri Dalam Negeri}

Berdasarkan Pasal 232 Peraturan Menteri Dalam Negeri Nomor 13 Tahun 2006 tentang Pedoman Pengelolaan Keuangan Daerah (2006:76), menyatakan bahwa "Sistem Akuntansi Pemerintahan Daerah merupakan serangkaian prosedur, mulai dari proses pengumpulan data, pencatatan, pengikhtisaran sampai dengan pelaporan keuangan dalam rangka pertanggungjawaban pelaksanaan APBD yang dapat dilakukan secara manual atau menggunakan komputer."

Sistem Akuntansi Pemerintahan Daerah sekurang-kurangnya meliputi :

1. Prosedur Akuntansi Penerimaan Kas;

2. Prosedur Akuntansi Pengeluaran Kas;

3. Prosedur Akuntansi Aset Tetap/Barang Milik Daerah; dan

4. Prosedur Akuntansi Selain Kas.

Sistem Akuntansi Pemerintahan Daerah disusun dengan berpedoman pada prinsip pengendalian intern sesuai dengan Peraturan Pemerintah yang mengatur tentang pengendalian internal dan Peraturan Pemerintah tentang Standar Akuntansi Pemerintahan. 
Dari pengertian di atas, dapat disimpulkan bahwa Sistem Akuntansi Keuangan Daerah (SAKD) merupakan sistem akuntansi yang terdiri dari seperangkat kebijakan, standar dan prosedur yang dapat menghasilkan laporan yang relevan, andal dan tepat waktu untuk menghasilkan informasi dalam bentuk laporan keuangan yang akan digunakan oleh pihak intern dan pihak ekstern pemerintah daerah untuk mengambil keputusan ekonomi.

\section{Konsep Sistem Informasi Manajemen Daerah}

Sistem Informasi merupakan suatu sistem yang cukup kompleks. Sistem ini dapat berjalan dengan baik apabila semua proses didukung dengan teknologi yang tinggi, sumber daya yang berkualitas dan yang paling penting komitmen perusahaan. Supaya informasi yang dihasilkan oleh sistem informasi dapat berguna bagi manajemen, maka analis sistem harus mengetahui kebutuhan-kebutuhan informasi yang dibutuhkannya, yaitu dengan mengetahui kegiatan-kegiatan untuk masing-masing tingkat (level) manajemen dan tipe keputusan yang diambilnya.

\section{Penelitian Terdahulu}

Yunie Melka Kalantouw dengan judul "Analisis Penerapan Akuntansi Berdasarkan PSAP (PP Nomor 24 Tahun 2005) Atas Penyusunan Laporan Keuangan Pemerintah Provinsi Sulawesi Utara. Metode penelitian yang dipakai yaitu Metode Analisis Deskriptif yaitu dengan membandingkan penyusunan Laporan keuangan yang dimiliki Pemerintah Provinsi Sulawesi Utara dengan PSAP (Peraturan Pemerintah Nomor 24 Tahun 2005) yang berlaku di Indonesia sebagai acuan penerapan akuntansi berbasis kas menuju akrual.

Hasil penelitian adalah Pemerintah Provinsi Sulawesi Utara menerapkan basis kas menuju akrual sebagaimana diamanatkan dalam Peraturan Pemerintah Nomor 24 Tahun 2005 tentang Standar Akuntansi Pemerintahan yang merupakan standar akuntansi pada masa transisi dari kas menuju akrual menjadi basis akrual penuh. Persamaan dengan penelitian ini dan penelitian yang penulis lakukan adalah sama-sama meneliti tentang Sistem Informasi Akuntansi pada Pemerintah Daerah. Namun ada perbedaan dalam penelitian ini yaitu penelitian terdahulu menganalisa penerapan akuntansi terhadap proses penyusunan Laporan Keuangan dengan acuan Peraturan Pemerintah Nomor 24 Tahun 2005, sedangkan penulis mengevaluasi prosedur pengeluaran kas melalui aplikasi SIMDA Keuangan yang telah diterapkan dengan mengacu kepada Peraturan Menteri Dalam Negeri Nomor 13 Tahun 2006.

\section{METODE PENELITIAN}

\section{Jenis Penelitian}

Data yang digunakan adalah data kualitatif. Data yang dugunakan dalam penelitian ini adalah data kualitatif yaitu data yang diperoleh dari objek penelitian yang berbentuk kalimat atau uraian, sketsa maupun gambar, seperti company profile (sejarah perusahaan, struktur organisasi dan salinan copy berkas perusahaan) dan tanya-jawab.

\section{Tempat dan Waktu Penelitian}

Penelitian dilakukan pada Dinas Pendapatan Pengelolaan Keuangan dan Asset Daerah Kota Kotamobagu yang berlokasi di Jalan Ahmad Yani No. 02 Kota Kotamobagu (95711).Waktu penelitian dilakukan pada tanggal 1 Desember 2014 s/d 12 Februari 2015.

\section{Metode Pengumpulan Data}

Observasi (Obserrvation), yaitu dengan cara melakukan pengamatan langsung ke lapangan dalam hal ini Dinas Pendapatan, Pengelolaan Keuangan Dan Aset Daerah Kota Kotamobagu untuk memperoleh data dan informasi tentang penerapan SIMDA Keuangan di lingkungan Dinas Pendapatan, Pengelolaan Keuangan Dan Aset Daerah Kota Kotamobagu Wawancara (Interview), yaitu teknik pengumpulan data dengan melakukan tanya jawab atau wawancara dengan pihak-pihak yang berhubungan dengan SIMDA Keuangan, antaralain PPTK (Pejabat Pelaksana Teknis Kegiatan), Bendahara Pengeluaran Pembantu, PPK (Pejabat Penatausahaan Keuangan) dan staf pembantu PPK.

\section{Metode Analisis Data}


Dalam penulisan ini penulis menggunakan metode analisis deskriptif kualitatif yaitu metode dimana data yang dikumpulkan disusun, dikelompokkan, diinterprestasikan, dan dianalisis untuk mengetahui bagaimana penerapan SIMDA Keuangan pada Dinas Pendapatan, Pengelolaan Keuangan Dan Aset Daerah Kota Kotamobagu.

\section{HASIL PENELITIAN DAN PEMBAHASAN}

\section{Gambaran Umum Objek Penelitian Deskripsi Objek Penelitian}

Kota Kotamobagu merupakan wilayah hasil Pemekaran Kabupaten Bolaang Mongondow berdasarkan Undang - undang Nomor 04 tahun 2007 tentang Pembentukan Kota Kotamobagu. Secara Geografis Kota Kotamobagu terletak pada posisi $124^{0} 15^{\prime} 9,566^{\prime \prime}-124^{0} 21^{\prime} 1,93^{\prime \prime}$ Lintang Utara dan $0^{\circ} 41^{\prime} 16,29^{\prime \prime}-0^{\circ} 46^{\prime} 14,8^{\prime \prime}$ Bujur Timur. Batas-batasnya meliputi sebagai berikut:

- Sebelah utara : Kec. Bilalang Kab. Bolaang Mongondow

- Sebelah timur : $\quad$ Kec. Modayag Kab. Bolaang Mongondow Timur

- Sebelah selatan : Kec. Lolayan Kab. Bolaang Mongondow

- Sebelah barat : Kec. Passi Barat Kab. Bolaang Mongondow

Kota Kotamobagu secara administratif memiliki luas wilayah $184,43 \mathrm{~km}^{2}$ atau $9,92 \%$ dari luas Kabupaten Bolaang Mongondow. Wilayah tersebut terbagi 4 Kecamatan, 14 Desa dan 18 Kelurahan. Sedangkan Penduduk Kota Kotamobagu hingga akhir tahun 2007 berjumlah 99.068 jiwa.

\section{Dinas Pendapatan Pengelolaan Keuangan dan Aset Daerah}

Dinas Pendapatan Pengelolaan Keuangan dan Aset Daerah adalah unsur pelaksana otonomi daerah dipimpin oleh seorang Kepala Dinas yang berada dibawah dan bertanggung jawab kepada Walikota. Dalam penelitian ini yang menjadi objek penelitian yaitu Kota Kotamobagu, yang berlokasi di Jalan Ahmad Yani No. 02 Kota Kotamobagu 95711.

Dinas Pendapatan Pengelolaan Keuangan dan Aset Daerah mempunyai fungsi yaitu sebagai berikut.

1. Perumusan kebijakan teknis dibidang pendapatan, pengelolaan keuangan dan aset daerah

2. Penyelenggaraan urusan pemerintahan dan pelayanan umum dibidang Pendapatan, Pengelolaan Keuangan dan

aset daerah

3. Pembinaan dan pelaksanaan tugas di bidang pendapatan, pengelolaan keuangan dan aset daerah

4. Pembinaan Unit Pelaksana Teknis Dinas

5. Pelaksanaan urusan tata usaha dinas

6. Pelaksanaan tugas lain yang diberikan oleh Walikota sesuai dengan tugas dan fungsinya.

Dinas Pendapatan Pengelolaan Keuangan dan Aset Daerah mempunyai tugas melaksanakan urusan pemerintahan daerah berdasarkan asas otonomi dan tugas pembantuan dibidang pendapatan, pengelolaan keuangan dan asset daerah.

Penyelenggaraan urusan pemerintahan dan pelayanan umum sebagai berikut.

1. Pembinaan dan pelaksanaan tugas dibidang pendapatan, pengelolaan keuangan dan asset daerah

2. Pembinaan Unit Pelaksana Teknis Dinas

3. Pelaksanaan urusan tata usaha dinas

4. Pelaksanaan tugas lain yang diberikan oleh Walikota sesuai dengan tugas dan fungsinya

Kepala dinas bertindak selaku Pejabat Pengelola Keuangan Daerah mempunyai tugas membantu Walikota dalam rangka pelaksanaan tugas desentralisasi dibidang pendapatan, pengelolaan keuangan dan pengelolaan asset daerah.

Untuk menyelenggarakan tersebut, Kepala Dinas Pendapatan Pengelolaan Keuangan dan Aset Daerah mempunyai fungsi sebagai berikut.

1. Merumuskan program kegiatan dibidang pendapatan, pengelolaan keuangan dan pengelolaan aset daerah

2. Menyelenggarakan urusan administrasi kesekretariatan instansi

3. Mengkaji dan menggali potensi sumber pendapatan asli daerah

4. Menyelenggarakan urusan pendaftaran usaha-usaha investasi sebagai sumber pendapatan retribusi

5. Menyelenggarakan kegiatan penagihan retribusi sebagai sumber pemasukan keuangan

6. Menyelenggarakan kegiatan manajemen dan akuntansi keuangan yang sistematis dan terpadu sesuai norma, 
standar dan pengelolaan keuangan yang berlaku

7. Menyelenggarakan kegiatan pengelolaan aset daerah.

8. Menyelenggarakan penyusunan Anggaran Pendapatan dan Belanja Daerah serta kegiatan perubahan terhadap APBD

9. Melasanakan monitoring dan pemantauan terhadap pengelolaan keuangan SKPD di lingkungan Pemerintah Daerah

10. Melakukan pembinaan pengelolaan keuangan bagi para pelaksana bendahara keuangan disetiap SKPD

11. Membuat Laporan Pelaksanaan Tugas kepada Pimpinan

12. Melaksanakan tugas lain yang diberikan oleh pimpinan

\section{Hasil Penelitian}

\section{Laporan Keuangan}

1. Laporan Realisasi Anggaran (LRA)disajikan sekurang-kurangnya sekali dalam setahun.

2. Neraca menggambarkan posisi keuangan suatu entitas pelaporan mengenai asset, kewajiban, dan ekuitas pada tanggal tertentu. Unsur yang dicakup oleh neraca terdiri dari aset, kewajiban dan ekuitas.

3. Catatan atas Laporan Keuangan meliputi penjelasan naratif atau rincian dari angka yang tertera dalam Laporan Realisasi Anggaran, Neraca dan Laporan Arus Kas.

\section{Prosedur Akuntansi Keuangan Daerah Pada SKPD}

Prosedur Akuntansi Keuangan Daerah pada SKPD meliputi prosedur akuntansi penerimaan kas pada SKPD, prosedur akuntansi pengeluaran kas pada SKPD, prosedur akuntansi asset pada SKPD dan prosedur akuntansi selain kas pada SKPD.

\section{Prosedur Akuntansi Pengeluaran Kas Pada SKPD}

Prosedur akuntansi pengeluaran kas pada SKPD meliputi serangkaian proses mulai dari pencatatan, pengikhtisaran, sampai dengan pelaporan keuangan yang berkaitan dengan pengeluaran kas dalam rangka pertanggungjawaban pelaksanaan APBD. Prosedur Pengeluaran Kas terdiri atas 4 prosedur, yaitu

1. Prosedur Pengeluaran Kas - Uang Persediaan (UP)

2. Prosedur Pengeluaran Kas - Ganti Uang (GU)

3. Prosedur Pengeluaran Kas - Tambahan Uang (TU)

4. Prosedur Pengeluaran Kas - Pembebanan Langsung (LS)

\section{Pembahasan}

Setelah melakukan penelitian di Dinas Pendapatan, Pengelolaan Keuangan Dan Aset Daerah Kota Kotamobagu, peneliti melihat bahwa prosedur akuntansi pengeluaran kas yang diterapkan secara umum sudah berjalan dengan baik, namun belum seluruhnya sesuai dengan Peraturan Menteri Dalam Negeri Nomor 13 Tahun 2006 tentang Pedoman Pengelolaan Keuangan Daerah sehingga sekalipun penatausahaan keuangan telah berjalan dengan baik, tetapi masih kurang efektif dan efisien. Khususnya karena masih terdapat fungsi-fungsi dari beberapa unsur yang terkait dalam prosedur pengeluaran kas yang belum berjalan dengan semestinya.

Analisis Pencatatan dan Pelaporan Keuangan pada Satuan Kerja Perangkat Daerah (SKPD) di Pemerintah Kota Medan (Studi kasus pada Dinas Tata Kota Tata Bangunan)" pada tahun 2009.Metode penelitian yang dipakai yaitu Metode Analisis Deskriptif. Hasil penelitian menunjukkan bahwa Dinas Tata Kota Tata Bangunan Kota Medan telah menerapkan Sistem Pencatatan dan Pelaporan Keuangan sesuai dengan Peraturan Pemerintah Nomor 24 Tahun 2005 dan Peraturan Menteri Dalam Negeri Nomor 13 Tahun 2006 yang dimulai untuk Tahun Anggaran 2007. Persamaan dengan penelitian ini dan penelitian yang penulis lakukan adalah sama-sama memakai penerapan Peraturan Pemerintah Nomor 13 Tahun 2006.Namun ada perbedaan dalam penelitian ini yaitu penelitian yang terdahulu tidak mengevaluasi penerapan sistem informasi akuntansi tetapi menganalisis pencatatan dan pelaporan keuangan.

\section{PENUTUP}

\section{Kesimpulan}

Kesimpulan dalam penelitian ini adalah penerapan SIMDA Keuangan pada Dinas Pendapatan, Pengelolaan Keuangan Dan Aset Daerah Kota Kotamobagu belum sepenuhnya sesuai dengan Peraturan Perundangundangan yang berlaku, karena prosedur pengeluaran kas pada Dinas Pendapatan, Pengelolaan Keuangan Dan 
Aset Daerah belum sesuai dengan Peraturan Menteri Dalam Negeri Nomor 13 Tahun 2006 tentang Pedoman Pengelolaan Keuangan Daerah.

\section{Saran}

Saran dalam penelitian ini:

1. Untuk prosedur pengeluaran kas pada Dinas Pendapatan, Pengelolaan Keuangan Dan Aset Daerah Kota Kotamobagu, setiap unsur yang terlibat harus dapat melaksanakan tugas dan fungsinya masing-masing agar tidak terjadi tumpang tindih dalam pelaksanaan tugas dan fungsi pengendalian internal dari masing-masing unsur dapat berjalan baik, efektif dan efisien.

2. Agar setiap unsur yang terlibat dalam prosedur pengeluaran kas dapat melaksanakan tugas dan fungsinya dengan baik, perlu didukung dengan SDM yang handal dan terampil khususnya dibidang pengoperasian komputer, untuk itu perlu upaya pengembangan potensi PNS di lingkungan Setda Dinas Pendapatan, Pengelolaan Keuangan Dan Aset Daerah melalui kursus atau pelatihan komputer ataupun dengan cara merekrut pegawai baru yang memiliki keterampilan dan kemampuan yang sesuai dengan kebutuhan.

3. Untuk Tahun Anggaran selanjutnya hendaknya Dinas Pendapatan, Pengelolaan Keuangan Dan Aset Daerah dalam proses Pengeluaran Kas harus berpedoman pada Peraturan Perundang-undangan yang berlaku.

\section{DAFTAR PUSTAKA}

Kieso, Donald, Weygand, dan Warfield, (2008). Akuntansi Intermediate Edisi Keduabelas - Jilid 1, Erlangga, Jakarta.

Mulyadi (2005), "Akuntansi Biaya”, Edisi Kelima, Cetakan Ketujuh, Penerbit Akademi Manajemen Perusahaan YKPN, Yogyakarta.

Pemerintah Republik Indonesia. 2006.Peraturan Menteri Dalam Negeri Nomor 13 Tahun tetang Pedoman Pengelolaan Keuangan Daerah.

Pemerintah Republik Indonesia. 2007. Peraturan Menteri Dalam Negeri Nomor 59 TENTANG Perubahan Atas Peraturan Menteri Dalam Negeri Nomor 13 Tahun 2006 tentang Pedoman Pengelolaan Keuangan Daerah.

Pemerintah Republik Indonesia. 2011. Peraturan Menteri Dalam Negeri Nomor 21 tentang Perubahan Kedua Atas Peraturan Menteri Dalam Negeri Nomor 13 Tahun 2006 tentang Pedoman Pengelolaan Keuangan Daerah.

Harahap, Sofyan Safri (2011). Teori Akuntansi, Cetakan ke-11, Penerbit : Jakarta.

Wilopo. 2005.Ikhtisar Lengkap Pengantar Akuntansi, Edisi Dua, $\quad$ Penerbit FE UI, Jakarta.I

Surono. 2006. Akuntansi : Penekanan Managerial, Edisi ke sebelas, Salemba Empat, Jakarta.

Munawir. 2010. Akuntansi, Edisi Ketujuh Jilid 1, Lembaga Penerbit Erlangga, Jakarta.

Mulyadi. 2005. Akuntansi Biaya", Edisi Kelima, Cetakan Ketujuh, Penerbit $\quad$ Akademi Manajemen Perusahaan YKPN, Yogyakarta. 